\title{
Microbial Communities and Their Performances in Anaerobic Hybrid Sludge Bed-Fixed Film Reactor for Treatment of Palm Oil Mill Effluent under Various Organic Pollutant Concentrations
}

\author{
Kanlayanee Meesap, ${ }^{1}$ Nimaradee Boonapatcharoen, ${ }^{2}$ \\ Somkiet Techkarnjanaruk, ${ }^{2}$ and Pawinee Chaiprasert ${ }^{3}$ \\ ${ }^{1}$ The Joint Graduate School of Energy and Environment, King Mongkut's University of Technology Thonburi, Bangkok 10140, Thailand \\ ${ }^{2}$ Excellent Center of Waste Utilization and Management, National Center for Genetic Engineering and Biotechnology at King Mongkut's \\ University of Technology Thonburi Bang Khun Thian, Bangkok 10150, Thailand \\ ${ }^{3}$ Division of Biotechnology, School of Bioresources and Technology, King Mongkut's University of Technology Thonburi Bang \\ Khun Thian, Bangkok 10150, Thailand
}

Correspondence should be addressed to Pawinee Chaiprasert, pawinee.cha@kmutt.ac.th

Received 21 February 2012; Revised 10 April 2012; Accepted 17 May 2012

Academic Editor: Daniele Daffonchio

Copyright (c) 2012 Kanlayanee Meesap et al. This is an open access article distributed under the Creative Commons Attribution License, which permits unrestricted use, distribution, and reproduction in any medium, provided the original work is properly cited.

The anaerobic hybrid reactor consisting of sludge and packed zones was operated with organic pollutant loading rates from 6.2 to $8.2 \mathrm{~g} \mathrm{COD} / \mathrm{L}$ day, composed mainly of suspended solids (SS) and oil and grease (O\&G) concentrations between 5.2 to 10.2 and 0.9 to $1.9 \mathrm{~g} / \mathrm{L}$, respectively. The overall process performance in terms of chemical oxygen demands (COD), SS, and O\&G removals was 73,63 , and $56 \%$, respectively. When the organic pollutant concentrations were increased, the resultant methane potentials were higher, and the methane yield increased to $0.30 \mathrm{~L} \mathrm{CH}_{4} / \mathrm{g} \mathrm{COD}_{\text {removed }}$. It was observed these effects on the microbial population and activity in the sludge and packed zones. The eubacterial population and activity in the sludge zone increased to $6.4 \times 10^{9}$ copies $\mathrm{rDNA} / \mathrm{g}$ VSS and $1.65 \mathrm{~g}$ COD/g VSS day, respectively, whereas those in the packed zone were lower. The predominant hydrolytic and fermentative bacteria were Pseudomonas, Clostridium, and Bacteroidetes. In addition, the archaeal population and activity in the packed zone were increased from to $9.1 \times 10^{7}$ copies $\mathrm{rDNA} / \mathrm{g}$ VSS and $0.34 \mathrm{~g} \mathrm{COD}-\mathrm{CH}_{4} / \mathrm{g}$ VSS day, respectively, whereas those in the sludge zone were not much changed. The most represented species of methanogens were the acetoclastic Methanosaeta, the hydrogenotrophic Methanobacterium sp., and the hydrogenotrophic Methanomicrobiaceae.

\section{Introduction}

Palm oil production is the second largest edible oil output and accounts for approximately $23 \%$ fof the world's fat and oil supply, which is approximately $2.8 \times 10^{10}$ tons [1]. Palm oil is now not only being used as edible oil, but also in the production of biodiesel as a renewable energy source. In 2009, Thailand consumed 24,872 ktoe of alternative energy sources, and biodiesel accounted for 3.2\%, the demand for which is continually increasing [2]. Biodiesel is set as one of the renewable energy sources in Thailand's strategic plan, which recently used $1.62 \times 10^{6} \mathrm{~L} /$ day. The target for biodiesel production by the year 2021 is planned to produce $5.97 \times$ $10^{6} \mathrm{~L} /$ day [3]. Therefore, the palm oil industry in Thailand is expanding rapidly for production of edible oil, biodiesel, and other applications. The expansion of crude palm oil production will generate additional wastewater at an increasing rate.

Environmental impacts from wastewater of palm oil production known as palm oil mill effluent (POME) are a matter of great concern. POME contains large quantities of high organic pollutants. 42.7 million tons of palm oil were produced globally in 2008 [4]. POME is one of the most 
significant pollutants associated with its voluminous production [5]. For every ton of palm oil production, 2.5-3.0 tons of POME is generated $[6,7]$. It has been classified as a high-strength wastewater due to its high biochemical oxygen demand (BOD) and chemical oxygen demand (COD), consisting of high organic pollutant concentrations in suspended solids (SS) and lipid or oil and grease (O\&G). Fresh POME is an acidic ( $\mathrm{pH} 3.5-4.5)$, brownish, viscous, and voluminous colloidal suspension being $95-96 \%$ water, $10-44 \mathrm{~g} / \mathrm{L}$ of BOD, $16-100 \mathrm{~g} / \mathrm{L}$ of COD, $5-45 \mathrm{~g} / \mathrm{L}$ of SS, $1-15 \mathrm{~g} / \mathrm{L}$ of $\mathrm{O} \& \mathrm{G}$, and $0.2-0.5 \mathrm{~g} / \mathrm{L}$ of total nitrogen $[8,9]$.

Biological treatment of POME is the most frequently used treatment method. Since it contains high concentrations of organic matter, adoption of anaerobic digestion $(\mathrm{AD})$ in the first stage of the process is needed to convert the bulk of the wastewater to biomethane. $\mathrm{AD}$ is a multistep degradation of the organic compounds into biogas, methane, and carbon dioxide, by the action of a microbial consortium [10]. The metabolic reactions that occur during the anaerobic digestion of the substrates involve four important reactions: hydrolysis, acidogenesis, acetogenesis, and methanogenesis [11]. In general of $\mathrm{AD}$, methanogenesis is the rate-limiting step. As such, conventional anaerobic digesters require long hydraulic retention time and large volume reactors to ensure the complete treatment of the influent. Nonetheless, high-rate anaerobic bioreactors have been proposed to reduce reactor volume, shorten retention time, and capture methane gas for utilization. The anaerobic hybrid reactor (AHR), like the upflow anaerobic sludge bedfixed film reactor, was found to be high performing in COD removal efficiency and methane production [5]. This hybrid system can overcome the existing deficiencies of the original upflow anaerobic sludge blanket (UASB) reactors by shortening the biogranule formation time [12]. Upflow AHRs can work well for the high-suspended solid pollutants like cassava starch wastewater, slaughterhouse waste, and POME [12-15]. Therefore, this study applied AHR, a combination of two zones in the reactor, namely, the sludge zone (part of the microbial granules) and the packed zone (part of the biofilm on the packing material) for the anaerobic treatment of POME.

The major components in biological anaerobic digestion, microorganisms, play an important role as the main function in controlling reactor performance and stability. The performance and stability of an anaerobic digester is directly related to the quantity and quality of the microbial community present in the digester. Furthermore, the operational and environmental parameters of the process obviously affect the microbial behavior resulting in wastewater treatment and biogas production performances [11]. SSs containing palm fiber and O\&G are the main organic pollutants in POME. In this study, we looked specifically at the concentrations of these organic pollutants in the organic digestion of AHR. This work focused on the effect of the organic pollutant concentrations on the process performance and stability, that is, the microbial communities and the microbial performance in the sludge and packed zones of the AHR. The work will lead to an understanding of the operational efficiency of the AHR system, depending on the structure of the microbial
TABLE 1: Average composition of POME influents under various operating conditions.

\begin{tabular}{lccccc}
\hline Condition & $\begin{array}{c}\text { OLR } \\
\text { (g COD/L day })\end{array}$ & $\begin{array}{c}\text { TCOD } \\
(\mathrm{g} / \mathrm{L})\end{array}$ & $\begin{array}{c}\text { SCOD } \\
(\mathrm{g} / \mathrm{L})\end{array}$ & $\begin{array}{c}\text { SS } \\
(\mathrm{g} / \mathrm{L})\end{array}$ & $\begin{array}{c}\text { O\&G } \\
(\mathrm{g} / \mathrm{L})\end{array}$ \\
\hline $\mathrm{C} 1$ & 6.2 & 30.6 & 18.4 & 5.2 & 0.9 \\
$\mathrm{C} 2$ & 7.6 & 38.4 & 24.6 & 7.1 & 1.4 \\
$\mathrm{C} 3$ & 8.2 & 40.4 & 28.6 & 10.2 & 1.9 \\
\hline
\end{tabular}

Values are averages of three determinations with standard deviations lower than $5 \%$ between analyses.

communities present in the system and the environmental conditions needed to control the system.

\section{Materials and Methods}

2.1. Wastewater Characteristics. Raw POME was collected from a palm oil production plant in Thailand. The raw POME characteristics were determined according to the procedures of the standard methods of wastewater analysis [16]. Its characteristics were in the range of total chemical oxygen demand (TCOD) $57-63 \mathrm{~g} / \mathrm{L}$, soluble chemical oxygen demand (SCOD) $40-44 \mathrm{~g} / \mathrm{L}$, SS $25-38 \mathrm{~g} / \mathrm{L}$, and O\&G 9$13 \mathrm{~g} / \mathrm{L}$ with $\mathrm{pH} 4.5-4.8$. To study the influence of SS combining with O\&G concentrations, influent POME was prepared by varying the $S S$ and $O \& G$ concentrations into three conditions, $\mathrm{C} 1, \mathrm{C} 2$, and $\mathrm{C} 3$. These three operating conditions of the POME were fed into the reactor as shown in Table 1.

2.2. Reactor Configuration and Operation. A schematic diagram of the anaerobic hybrid sludge bed-fixed film reactor (AHR) used in this study is shown in Figure 1. The AHR was made up of an acrylic column with a working volume of 5.0 L. The bottom half of the reactor was occupied by the sludge zone and the upper half was occupied by the packed zone. This packed zone was fitted with nylon fibers having a specific surface area $150 \mathrm{~m}^{2} / \mathrm{m}^{3}$ for microbial attachment as biofilm formation. Seven sampling ports were distributed at several heights in the sludge and packed zones in the AHR. The influent was fed upflow from the bottom to the upper part of the AHR, and the treated wastewater was discharged through an effluent port. The AHR was initially fed with $5.0 \mathrm{~L}$ of diluted POME and inoculated with startup seed, which was collected from the $\mathrm{AD}$ of the POME treatment at a final concentration of $5.0 \mathrm{~g} \mathrm{VSS} / \mathrm{L}$. For acclimatization of the startup seed to a new environment, $1 \mathrm{~L}$ of diluted POME influent was fed semicontinuously once a day with a hydraulic retention time (HRT) of 5 days for 20 days. Upon reactor startup operation, three experiments were set up by increasing the organic pollutant concentrations to $\mathrm{C} 1, \mathrm{C} 2$, and C3 (Table 1). The influent was upflow fed semi-continuously at constant HRT of 5 days. The reactor was operated in each condition until the process performance reached a steady state and was kept continually running for more than 3 cycles of HRT. 


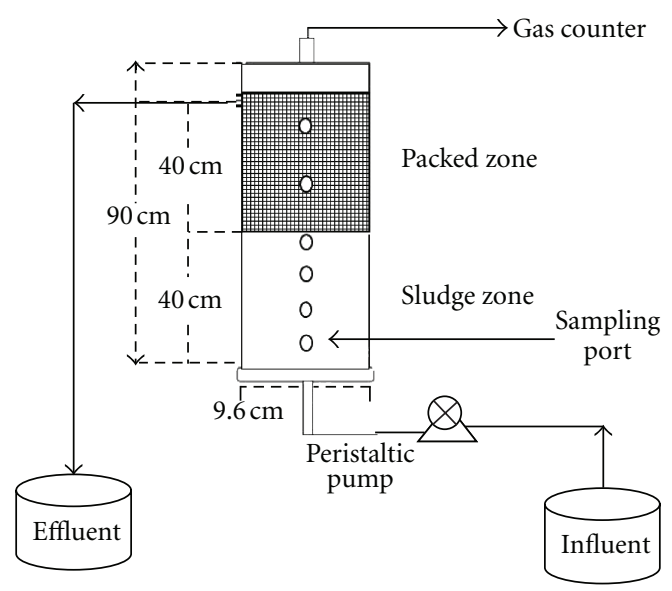

FIgURE 1: Schematic diagram of the laboratory-scale AHR.

The process performance of the sludge and packed zones, as well as the overall AHR, was routinely monitored through measurement of the TCOD, SCOD, alkalinity (Alk), total volatile acid (TVA), O\&G, SS, and the $\mathrm{pH}$ of the effluent POME. The TCOD, SCOD, SS, Alk, and TVA analyses were carried out according to the procedures of the standard methods of wastewater analysis [16]. The O\&G was analyzed by Soxhlet with hexane extraction according to AOAC methods [17]. The $\mathrm{pH}$ and biogas production were determined daily. The remaining parameters were measured three times a week throughout the steady-state period to ensure that representative data were obtained. Biogas composition was determined using gas chromatography [18].

2.3. Microbial Characteristics. At the end of each operating condition of $\mathrm{C} 1, \mathrm{C} 2$, and $\mathrm{C} 3$, suspended sludge samples from the sludge zone and the attached biofilm samples from the supporting media in the packed zone were collected. Microbial characteristics were determined by PCR-DGGE. DNA sequencing was carried out to determine the microbial community; 16S rDNA quantitative real-time PCR was used for the microbial quantity; microbial activity of nonmethanogens (eubacteria: EUB) and methanogens (archaea: ARC) was used for the microbial qualities.

2.3.1. PCR-DGGE and DNA Sequencing. To study the microbial communities, samples were collected aseptically from the reactor and immediately stored in a freezer for community analysis and prepared with a centrifugation method prior to DNA extraction. DNA extraction and amplification [19] and denaturing gradient gel electrophoresis (DGGE) were performed as previously described [20]. Sequences were initially compared to known $16 \mathrm{~S}$ rRNA gene sequences in the GenBank database using the BLASTn to locate nearly exact matches in the GenBank database [21].

2.3.2. 16s rDNA Quantitative Real-Time PCR. Copy numbers of $16 \mathrm{~S}$ rDNA of EUB and ARC were quantified by relative quantification real-time PCR (qPCR). A KAPA SYBR Fast qPCR Kit was used for real-time reactions (KAPA,
Brazil). The qPCR was performed using a fluorescencedetecting thermocycler (Stratagene Mx3005P). The two-step amplification protocol was as follows: initial denaturation for $10 \mathrm{~min}$ at $95^{\circ} \mathrm{C}$, followed by 40 cycles of $30 \mathrm{sec}$ at $95^{\circ} \mathrm{C}$ and combined annealing and elongation for $30 \mathrm{sec}$ at $60^{\circ} \mathrm{C}$. Standard curves were generated using $16 \mathrm{~S}$ rDNA of eubacteria and methanobacteria as standard EUB and ARC stains, respectively. The primer $8 \mathrm{~F} / \mathrm{U} 1492 \mathrm{R}$ was used to amplify $16 \mathrm{~S}$ rDNA of standard EUB. The primer A1F/U1492R was used to amplify 16S rDNA of standard ARC [20]. Amplicons of EUB and ARC were cloned to plasmid vector (pGEM-T Easy vector, Promega) and inserted in chemically competent cells (E. coli DH5 $\alpha$ ). Plasmids DNA were serially diluted in the range of $10^{2}-10^{7}$ copies $\mathrm{rDNA} / \mu \mathrm{L}$ and used as templates for qPCR with primers and amplification protocol as defined. The copy concentrations were calculated using the method of Whelan et al. [22].

2.3.3. Microbial Activity. Determination of microbial activity was carried out in triplicate using $120 \mathrm{~mL}$ vials with $50 \mathrm{~mL}$ of working volume. The inoculum-substrate ratio in the final volume was 30:70 v/v. Glucose and acetate were used as the substrates for activity analysis of the EUB and ARC, respectively. Determination of microbial activity was performed using the method of Nopharatana et al. [23].

2.4. Statistical Analysis. In this study, the standard errors were all within $5 \%$ of the mean value. A test of significant difference based on the paired t-statistic was performed using the MINITAB software (Minitab Inc., USA). The difference was regarded as nonsignificant if the paired $t$-statistic showed Probability, $P>0.05$ and significant if $P \leq 0.05$.

\section{Results and Discussion}

3.1. Reactor Performances and Stabilities. The AHR was operated for 144 days consecutively by increasing the organic pollutant ( $S S$ and $O \& G$ ) concentrations under the three conditions, $\mathrm{C} 1, \mathrm{C} 2$, and $\mathrm{C} 3$ (Table 1). The operating dates for the $\mathrm{C} 1, \mathrm{C} 2$, and $\mathrm{C} 3$ conditions were 40, 51, and 53 days, respectively. Once each operating condition reached a steady state of process performance, the reactor was run for a further 20 to 25 days ( $>3$ cycles of HRT) to ensure that representative data from the steady-state period were obtained and could yield shown values in mean and standard deviation from ten to fifteen determinations. Figure 2 shows the overall process performance during the steady state of the anaerobic bioreactor under $\mathrm{C} 1, \mathrm{C} 2$, and $\mathrm{C} 3$ conditions. Production of biogas was obtained at $2100 \pm 60,3300 \pm 35$, and $6400 \pm 75 \mathrm{~mL} /$ day for $\mathrm{C} 1, \mathrm{C} 2$, and C3, respectively. The methane yield coefficient is defined as the ratio of methane produced in this experiment to the COD utilized. The methane content in the biogas was approximately $65 \pm 2 \%$. The paired $t$-test analysis of the methane yielded $(P \leq 0.05)$, indicating that $\mathrm{C} 1, \mathrm{C} 2$, and $\mathrm{C} 3$ produced methane yield at significantly different rates. The methane yield increased corresponding to the increase of the SS and O\&G concentration. Under C1 and C2, methane yields of $0.13 \pm 0.01$ and 


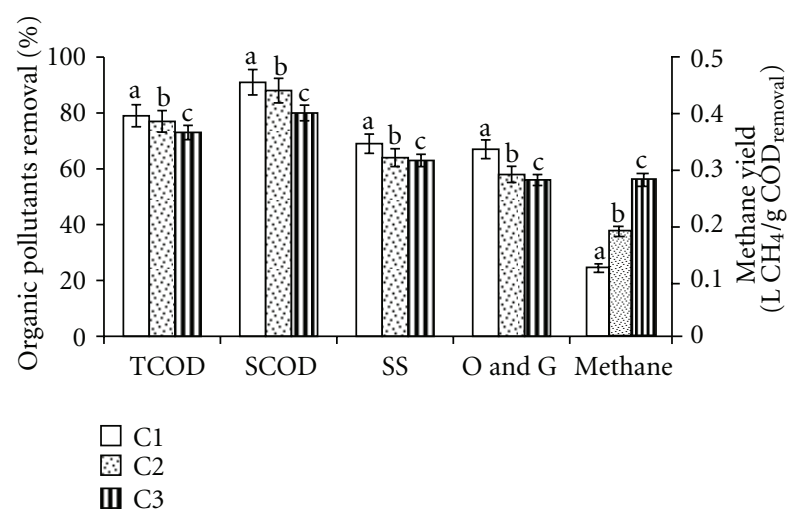

FIGURE 2: Overall process performances in organic pollutants removal and methane yields.

$0.20 \pm 0.01 \mathrm{~L} \mathrm{CH}_{4} / \mathrm{g} \mathrm{COD}_{\text {removed}}$, respectively, were obtained. Under C1 operation, a low methane yield was obtained, which was similar to the result found by Chaiprasert et al. [14] and Poh and Chong [5], likely due to the organic carbon (COD) being consumed by microorganisms to build more cells during the initial startup period. Under the C3 operation, the methane yield was up to $0.30 \pm 0.02 \mathrm{~L} \mathrm{CH}_{4} / \mathrm{g}$ $\mathrm{COD}_{\text {removed }}$. This value was close to the theoretical methane yield of $0.35 \mathrm{~L} \mathrm{CH}_{4} / \mathrm{g} \mathrm{COD}_{\text {removed. Considering a theoretical }}$ methane yield, the whole of the organic matter is transformed into methane, accounting for virtually negligible biomass growth and cell maintenance [24]. The AHR in this study showed the high effectiveness of the this reactor in converting the POME into methane at mesophilic temperatures with an organic loading rate (OLR) of $8.2 \mathrm{~g}$ COD/L day consisting of $10.2 \mathrm{~g} \mathrm{SS} / \mathrm{L}$ and $1.9 \mathrm{~g} \mathrm{O \& G} / \mathrm{L}$ with 5 days of HRT.

The process performance in terms of the efficiency of TCOD and SCOD removal was higher than 70\%. The SCOD was easily biodegradable and almost completely removed while the TCOD removal efficiency was between $70-80 \%$. Insoluble COD in the form of SS and O\&G was slightly harder to biodegrade, and its removal was lower than $70 \%$ (Figure 2). The SS removal efficiency varied in the range of 60 to $70 \%$. SS is one of major organic components of POME. This suspended organic matter is cell walls, short fibers, hemicelluloses, and nitrogenous compounds of proteins, which are less biodegradable and require a longer retention time for satisfactory digestion [25]. In addition, the O\&G or lipid content was one of the least biodegradable organic materials. The increase of $\mathrm{O} \& \mathrm{G}$ concentration from the $\mathrm{C} 1$ to the C3 operation showed a decrease in O\&G removal. An inhibitory $\mathrm{AD}$ process by lipids was found in the other studies and indicated as an impeding step of hydrolysis. The overall conversion rate was limited either by degradation of long-chain fatty acids (LCFAs) or by the physical processes of dissolution and mass transfer of these acids [26-28]. However, the removal efficiency of $O \& G$ in this study was in the range of 50 to $60 \%$. O\&G was generally hydrolyzed by bacterial enzymes under anaerobic conditions at an optimum $\mathrm{pH}$ value to a neutral value $[29,30]$. The slightly high
O\&G removal obtained in this study might arise from the suitable $\mathrm{pH}$ and stability of process with the ratio of TVA/Alk $<0.4$. The values of $\mathrm{pH}$ and ratio of TVA/Alk were $6.9 \pm 0.4$ and $0.35 \pm 0.02$, respectively. At this point, the environmental condition in the $\mathrm{AD}$ process can control the system to neutralize the $\mathrm{pH}$ with a high buffer capacity and less acidification risk leading to the high process stability [31].

Each zone of the AHR, the sludge and packed zones, was monitored and considered for its process performance and stability, as shown in Figures 3 and 4, respectively. Removal of the TCOD, SS, and O\&G in the sludge zone (Figure 3(a)) varied with an increase of the organic pollutant concentration. With a low organic pollutant concentration under the $\mathrm{C} 1$ condition, organic removal of TCOD, SS, and O\&G was more than $70 \%$. When the reactor was operated under the C2 and C3 conditions, increasing the organic pollutants, the removal decreased to $50 \%$. High concentrations of SS and O\&G in the POME influent caused a reduction in their removal because of the complex structure and less biodegradable compounds. Remaining undigested matter, which settled and accumulated in the sludge zone, was observed. Under the C2 and C3 operating conditions, TVA concentration sharply increased and was detected at $1400 \pm 15 \mathrm{mg} \mathrm{CH}_{3} \mathrm{COOH} / \mathrm{L}$ in the sludge zone (Figure 4(a)). Increasing the TVA concentration indicated that hydrolysis and acidogenesis had occurred in this sludge zone. The increase in the TVA concentration led to an increase in the ratio of TVA/Alk to $0.66 \pm 0.05$, and the $\mathrm{pH}$ was decreased to $6.5 \pm 0.1$ (Figure $4(\mathrm{a})$ ). A high TVA concentration in the sludge zone affected O\&G removal because an inappropriate $\mathrm{pH}$ level inhibited the activity of the extracellular lipase enzyme.

Organic pollutant removal in the packed zone is shown in Figure 3(b). High organic pollutant removal was achieved ( $>60 \%$ ), possibly due to the lower molecular weight or shorter chain compounds in the TCOD, SS, and O\&G obtained from the sludge zone, where they were more easily digested by anaerobic microorganisms. In the packed zone, the TVA concentration was lower than $800 \pm 10 \mathrm{mg} \mathrm{CH} \mathrm{CH}_{3} \mathrm{COOH} / \mathrm{L}$, leading to the $\mathrm{pH}$ and the ratio of TVA/Alk increasing to $6.9 \pm 0.2-7.4 \pm 0.2$ and $0.20 \pm 0.01-0.50 \pm 0.02$, respectively (Figure 4(b)). This environmental condition in the packed zone was suitable for supporting methanogens. Microbial consortiums were attached and grew on supporting media as biofilm in the packed zone, and they biodegraded organic acids to methane. The result was similar to the study of Suraruksa et al. [32], and this phenomenon showed that methanogenesis took place in the packed zone. The microbial community and characteristics will be explained further below.

Moreover, this study further increased the organic loading rate (OLR) from $8.2(\mathrm{C} 3)$ to $9.6 \mathrm{~g} \mathrm{COD} / \mathrm{L}$ day consisting of $11.3 \mathrm{~g} \mathrm{SS} / \mathrm{L}$ and $2.3 \mathrm{~g} \mathrm{O \& G/L}$. It was found that the process performance, that is, the organic pollutants removal and biogas production, was decreased, and the process stability tended to be unstable (data not shown). A short operation was run,f and the reactor started to fail. This AHR with 50\% of suspended growth and $50 \%$ of attached growth by volume 


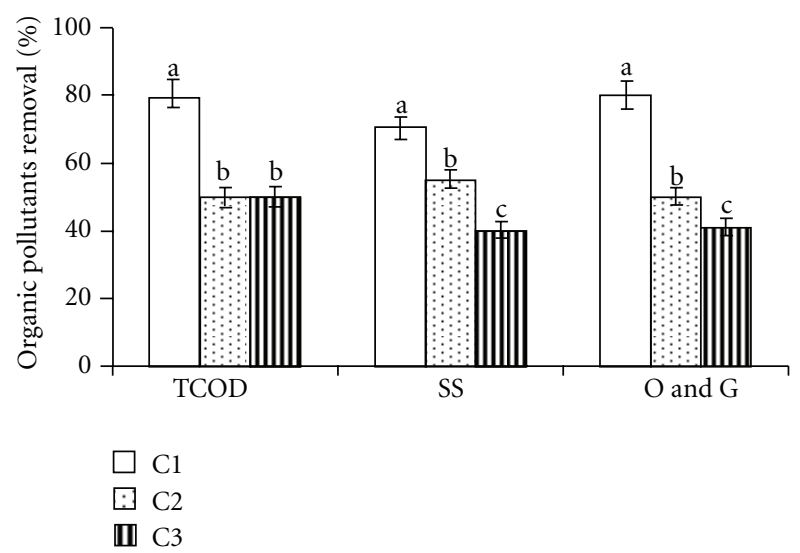

(a)

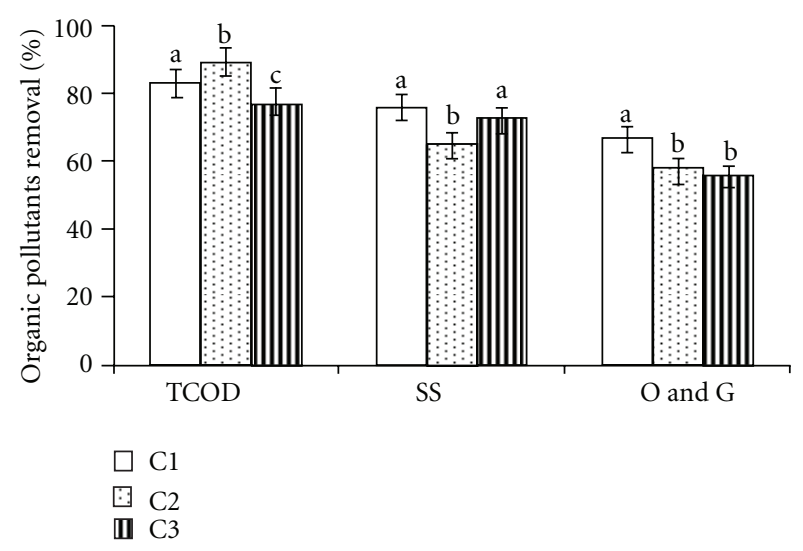

(b)

Figure 3: Process performances in (a) the sludge zone and (b) the packed zone of AHR.

can load high proportions of organic matter to $8.2 \mathrm{~g}$ COD/L day containing high SS $(10.2 \mathrm{~g} / \mathrm{L})$ and $\mathrm{O} \& \mathrm{G}(1.9 \mathrm{~g} / \mathrm{L})$. High process performance and stability were found. The capacity of organic loading fed to a high-rate anaerobic hybrid reactor for POME in this study was close to that in the study of Najafpour et al. [12].

3.2. Eubacterial and Archaeal Community. PCR-DGGE targeting the 16S rRNA genes of EUB and ARC was performed to investigate the microbial communities in the sludge and packed zones of the AHR at the operating conditions C1, $\mathrm{C} 2$, and C3. The DGGE profiles of the EUB (lane S, A-F) and the ARC (lane G-M) communities from all the samples in the startup seed and both the sludge and packed zones are illustrated in Figures 5(a) and 5(b), respectively. From Figures 5(a), and 5(b), the EUB band patterns were more complicated than those of the ARC due to the relatively higher diversity of domain EUB in most microbial complexes of hydrolytic, acidogenic, and acetogenic bacteria [33]. The partial 16S rRNA gene fragments from the selected bands in the DGGE profiles, twenty-two EUB and fifteen ARC bands, were sequenced, and affiliations were determined by comparison with the Genbank (Tables 2 and 3).

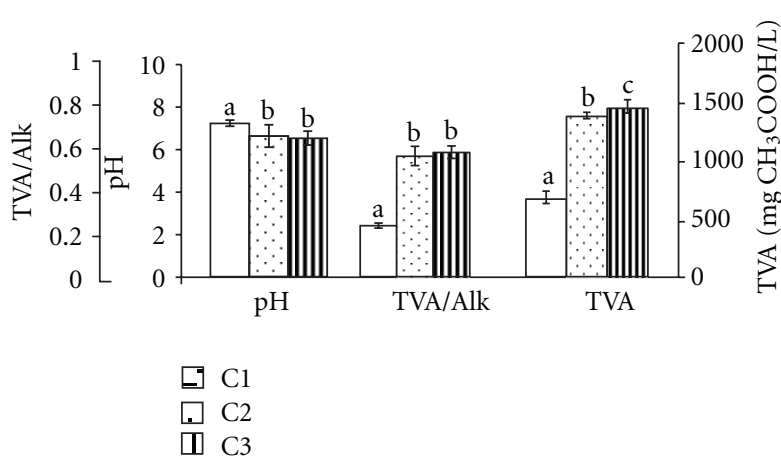

(a)

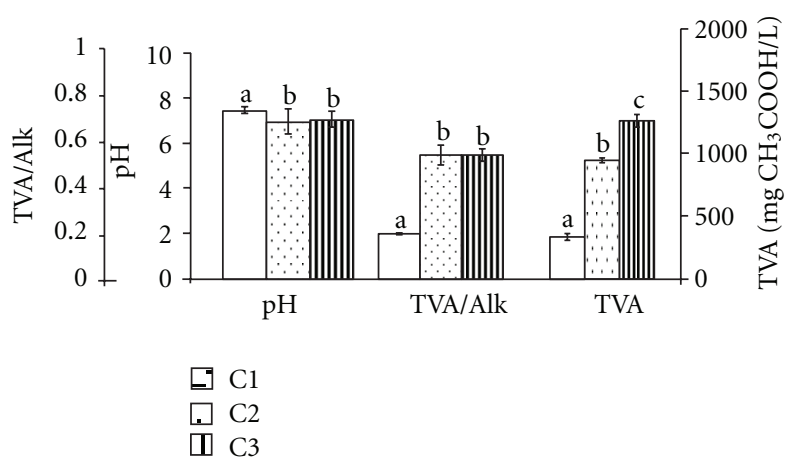

(b)

Figure 4: Process stabilities in (a) the sludge zone and (b) the packed zone of AHR.

In the startup seed, fourteen DGGE bands of the EUB communities (S1-14) and five bands of ARC communities (G1-5) as shown in Figures 5(a), and 5(b), respectively, were observed. These EUB communities were represented by hydrolytic bacteria-Pseudomonas sp. (S1, S3, S5-6, and S8-9) and Uncultured $\gamma$-proteobacterium (S10), acidogenic bacteria-uncultured Bacteroidetes bacterium (S7, S11-13), and acetogenic bacteria-Clostridiales bacterium (S2), Acetobacter sp. (S14), and uncultured Actinobacterium (S4), as shown in Table 2. Three of the five ARC bands were closely related to Methanobacterium sp. (G1-2) and Methanomicrobiaceae (G4), which were classified as hydrogenotrophic methanogens. The other two bands were closely related to the uncultured Methanococcoides sp. (G5) and uncultured Methanosaeta sp. (G3) belonging to the acetoclastic methanogens (Table 3).

The initial $\mathrm{C} 1$ condition was operated with the startup seed in the AHR for 40 days. The EUB communities in the packed zone (lane A) and in the sludge zone (lane B) were analyzed and are shown in Figure 5(a) and Table 2. Similar in the DGGE profiles of the EUB between the startup seed and C1, we found in S1-A1-B1 (Pseudomonas sp. M130), S5A4-B4 and S8-A7-B7 (Pseudomonas sp.), S7-A6-B6, S11-A9B8, S12-A10-B9, and S13-A11-B10 (uncultured Bacteroidetes bacterium), S2-A2-B2 (Clostridiales bacterium), and S14A12-B11 (Acetobacter sp.). The band intensity of A3, B3, and $\mathrm{A} 8$ increased during the operation period under $\mathrm{C} 1$ 
TABLE 2: The partial 16S rRNA gene sequences of EUB domain and organism with the best-matching sequences determined by BLAST searches.

\begin{tabular}{|c|c|c|c|c|c|c|c|c|c|}
\hline \multirow{2}{*}{ Affiliation } & \multicolumn{7}{|c|}{ DGGE band } & \multirow{2}{*}{ Similarity (\%) } & \multirow{2}{*}{ Accession no. } \\
\hline & Seed & \multicolumn{2}{|c|}{$\mathrm{C} 1$} & \multicolumn{2}{|c|}{$\mathrm{C} 2$} & \multicolumn{2}{|c|}{$\mathrm{C} 3$} & & \\
\hline \multicolumn{10}{|l|}{ Hydrolytic bacteria } \\
\hline Pseudomonas sp. M130 & S1 & A1 & B1 & $\mathrm{C} 1$ & D1 & E1 & $\mathrm{F} 1$ & 92 & AB088750.2 \\
\hline Pseudomonas entomophila str. L48 & S3 & & B3 & $\mathrm{C} 3$ & D3 & & & 92 & CT573326.1 \\
\hline Pseudomonas sp. & S5 & A4 & B4 & & & & & 97 & AM886092.1 \\
\hline Pseudomonadaceae bacterium & S6 & A5 & B5 & & & & & 94 & AB545745.1 \\
\hline Pseudomonas sp. & S8 & A7 & B7 & $\mathrm{C} 8$ & D8 & E7 & F6 & 97 & AM886092.1 \\
\hline Pseudomonas pseudoalcaligenes & S9 & A8 & & & D9 & & & 79 & AF140011.1 \\
\hline Uncultured $\gamma$-proteobacterium & S10 & & & & & & & 82 & EU167353.1 \\
\hline Uncultured Firmicutes bacterium & & & & C5 & D5 & & & 94 & FM896934.1 \\
\hline Uncultured $\gamma$-proteobacterium & & & & C9 & & E9 & F8 & 82 & EU167353.1 \\
\hline Uncultured $\gamma$-proteobacterium & & & & & & E8 & F7 & 82 & EU167353.1 \\
\hline Uncultured delta-proteobacterium & & & & & & E10 & & 73 & FN429803.1 \\
\hline \multicolumn{10}{|l|}{ Acidogenic bacteria } \\
\hline Uncultured Bacteroidetes bacterium & S7 & A6 & B6 & & & E6 & F5 & 94 & CU926845.1 \\
\hline Uncultured Bacteroidetes bacterium & S11 & A9 & B8 & $\mathrm{C} 10$ & D10 & & F9 & 98 & EU810898.1 \\
\hline Uncultured Bacteroidetes bacterium & S12 & A10 & B9 & & & E11 & F10 & 76 & GU955023.1 \\
\hline Uncultured Bacteroidetes bacterium & S13 & A11 & B10 & $\mathrm{C} 11$ & D11 & E12 & F11 & 91 & GU955023.1 \\
\hline Uncultured Bacteroidetes bacterium & & & & C6 & D6 & E5 & & 86 & AB433139.1 \\
\hline Uncultured Bacteroidetes bacterium & & & & $\mathrm{C} 7$ & D7 & & & 94 & CU926845.1 \\
\hline Bacteroides & & & & & & E3 & $\mathrm{F} 3$ & 87 & EU136682.1 \\
\hline \multicolumn{10}{|l|}{ Acetogenic bacteria } \\
\hline Clostridiales bacterium & S2 & A2 & $\mathrm{B} 2$ & $\mathrm{C} 2$ & $\mathrm{D} 2$ & $\mathrm{E} 2$ & $\mathrm{~F} 2$ & 81 & GU428556.1 \\
\hline Uncultured Actinobacterium & S4 & A3 & & $\mathrm{C} 4$ & D4 & & & 91 & GU194237.1 \\
\hline Acetobacter sp. & S14 & A12 & B11 & $\mathrm{C} 12$ & D12 & E13 & & 98 & GQ246703.1 \\
\hline Uncultured Clostridiaceae bacterium & & & & & & E4 & F4 & 74 & AB218300.1 \\
\hline
\end{tabular}

Remark: S: startup seed; A: packed zone and B: sludge zone at C1; C: packed zone and D: sludge zone at C2; E: packed zone and F: sludge zone at C3.

TABLE 3: The partial 16S rRNA gene sequences of ARC domain and organism with the best-matching sequences determined by BLAST searches.

\begin{tabular}{|c|c|c|c|c|c|c|c|c|c|}
\hline \multirow{2}{*}{ Affiliation } & \multicolumn{7}{|c|}{ DGGE band } & \multirow{2}{*}{ Similarity (\%) } & \multirow{2}{*}{ Accession no. } \\
\hline & Seed & \multicolumn{2}{|c|}{$\mathrm{C} 1$} & & & \multicolumn{2}{|c|}{$\mathrm{C} 3$} & & \\
\hline \multicolumn{10}{|l|}{ Acetoclastic methanogens } \\
\hline Uncultured Methanococcoides sp. & G5 & & I8 & J9 & K11 & L12 & M8 & 89 & AY454739.1 \\
\hline Uncultured Methanosaeta sp. & G3 & H6 & I6 & $\mathrm{J} 6$ & K8 & L9 & M6 & 85 & AY454766.1 \\
\hline Methanocaldococcus vulcanius M7 & & & $\mathrm{I} 2$ & & $\mathrm{~K} 2$ & $\mathrm{~L} 2$ & $\mathrm{M} 2$ & 90 & СР001787.1 \\
\hline \multicolumn{10}{|l|}{ Hydrogenotrophic methanogens } \\
\hline Methanobacterium sp. & G1 & $\mathrm{H} 4$ & I4 & $\mathrm{J} 4$ & K6 & L7 & M4 & 93 & GU936489.1 \\
\hline Methanobacterium sp. & G2 & H5 & I5 & $\mathrm{J} 5$ & K7 & L8 & M5 & 95 & GU569395.1 \\
\hline Methanomicrobiaceae & G4 & $\mathrm{H} 7$ & I7 & $\mathrm{J} 7$ & K9 & L10 & M7 & 87 & GU129124.1 \\
\hline Uncultured Methanomicrobiales & & $\mathrm{H} 1$ & I1 & $\mathrm{J} 1$ & K1 & L1 & M1 & 95 & AY780566.1 \\
\hline Methanospirillum hungatei & & $\mathrm{H} 2$ & & & & & & 99 & AB517987.1 \\
\hline Methanobacterium sp. & & $\mathrm{H} 3$ & I3 & $\mathrm{J} 3$ & $\mathrm{~K} 4$ & L4 & M3 & 97 & GU936489.1 \\
\hline Methanobacteriaceae & & & & & K5 & & & 89 & GU129060.1 \\
\hline Methanoculleus sp. & & & & $\mathrm{J} 8$ & K10 & L11 & & 96 & AB436897.1 \\
\hline Methanobacterium palustre & & & & & & L5 & & 91 & EU293795.1 \\
\hline Methanobacterium sp. & & & & & & L6 & & 95 & GU569395.1 \\
\hline
\end{tabular}

Remark: G: startup seed; H: packed zone and I: sludge zone at C1; J: packed zone and, K: sludge zone at C2; L: packed zone and M: sludge zone at C3. 


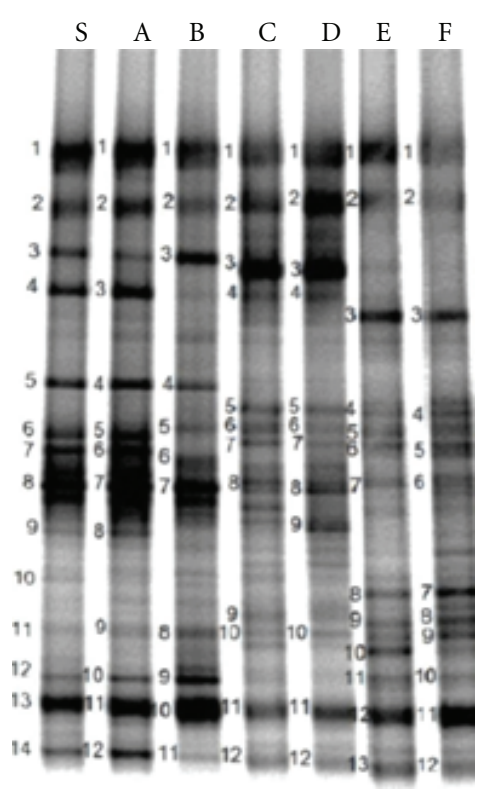

(a)

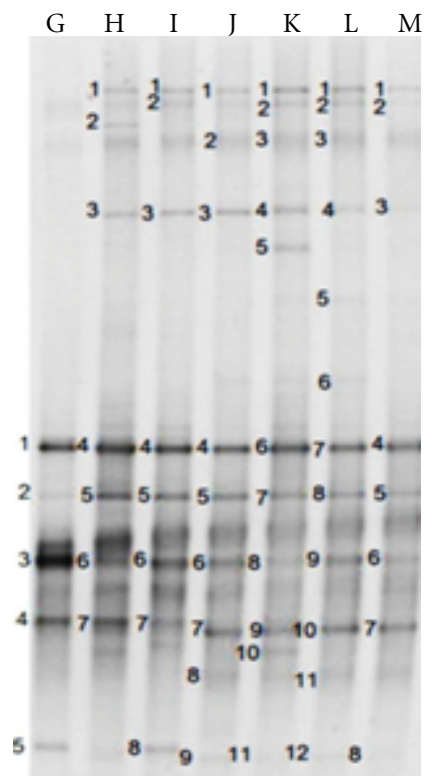

(b)

FIGURE 5: DGGE profiles of (a) EUB and (b) ARC of all reactor operations. Remark: (a) DGGE profile of EUB: S: startup seed; A: packed zone B: sludge zone at C1; C: packed zone and D: sludge zone at C2; E: packed zone and F: sludge zone at C3; (b) DGGE profile of ARC: G: startup seed; H: packed zone and I: sludge zone at C1; J: packed zone and K: sludge zone at C2; L: packed zone and M: sludge zone at C3.

(Figure 5(a)). A3, B3, and A8 were closely related to uncultured Actinobacterium, Pseudomonas entomophila str. L48, and Pseudomonas pseudoalcaligenes, respectively. The major EUB communities of hydrolytic, acidogenic, and acetogenic bacteria in the startup seed also existed during the initial reactor startup with slightly increased organic pollutant concentration ( $\mathrm{C} 1$ condition) which confers community stability during the beginning stage of anaerobic waste treatment $[34,35]$.

The DGGE band profiles showed some changes in the EUB community structure during the operations of the $\mathrm{C} 2$ and $\mathrm{C} 3$ conditions with the increase of the organic pollutant concentration. The EUB communities in the packed and sludge zones under operating conditions C2 and C3 are shown in C-D and E-F, respectively, (Figure 5(a)). Three hydrolytic bacteria of unculture Firmicutes bacterium (C5, D5), Uncultured $\gamma$-proteobacteria (C9, E8-9, F7-8), and uncultured delta proteobacterium (E10) were first detected in the DGGE band intensity under these conditions. Some of the initially predominant EUB bands, B3-C3-D3, and A8-D9, under C1 and C2 conditions became practically undetectable in the DGGE profile after increasing the organic pollutants to the $\mathrm{C} 3$ condition. Those sequence were related to Pseudomonas entomophila str. L48 and Pseudomonas pseudoalcaligenes, respectively. The sharp intensity bands of E3F3 and E8-F7 were detected after increasing the organic pollutant to the $\mathrm{C} 3$ condition. These were related to Bacteriodes and Uncultured Clostridiaceae bacterium in the groups of hydrolytic and acetogenic bacteria, respectively. The DGGE bands of E4-F4 (Uncultured Clostridiaceae bacterium) in the operating condition of C3 were also detected. Pseudomonas sp. M130 (A1-F1), Uncultured Bacteroidetes bacterium (A11B10-C11-D11-E12-F11), and Clostridiales bacterium (A2-F2) were observed throughout the operating conditions of $\mathrm{C} 1$ to C3 (Figure 5(a) and Table 2). The hydrolytic bacteria for lipid decomposition, Pseudomonas sp., is one of the predominant bacteria in the anaerobic digestion system. It has an ability to produce extracellular lipase enzymes that hydrolyze triglycerides to fatty acids and glycerol, and is generally found in lipid-contaminated wastewater [36]. With an increase of the organic pollutant of O\&G concentration at $1.9 \mathrm{~g} / \mathrm{L}$ under the C3 operating condition, Pseudomonas entomophila str. L48 and Pseudomonas pseudoalcaligenes disappeared because of the inhibition of the O\&G. However, Pseudomonas sp. M130 was found to exist in O\&G at the concentration of 0.9-1.9 g/L during the operation of the C1 to C3 conditions. Moreover, with the increase of organic loading from $\mathrm{C} 1$ to $\mathrm{C} 3$, the SS concentration also increased, and $\gamma$-proteobacteria was found to be dominant at the high SS concentration of $10.2 \mathrm{~g} / \mathrm{L}$ (C3 condition). This is a common representative of the microbial communities in anaerobic processes of solid substrates [37]. Uncultured Bacteroidetes bacterium, as an acidogenic bacterium, was only one species found under all operation conditions $(\mathrm{C} 1-\mathrm{C} 3)$ in this study, and it is one of the major microbial components of acidogenesis in $\mathrm{AD}$, as shown in other studies [38-40]. In acidogenesis, simple organic compounds are transformed into fermentation endoproducts such as lactate, propionate, acetate, and ethanol including $\mathrm{H}_{2}$ and $\mathrm{CO}_{2}$. This acidogenic bacterium can exist in low and high TVA concentrations, as found in this study at the range of $500-1500 \mathrm{mg} \mathrm{CH}_{3} \mathrm{COOH} / \mathrm{L}$ (Figure 4). The detected acetogenic bacteria were members 
of Firmicutes, mostly represented by Clostridiales bacterium and Acetobacter sp., which were found in the sludge and packed zones throughout the reactor operation. The exception was Uncultured Clostridiaceae bacterium, which was only found under the C3 condition. The acetate product from this acetogenic activity was transformed into methane by methanogens [41]. However, Firmicutes and Actinobacteria are known to produce cellulases, lipases, proteases, and other extracellular enzymes [39], suggesting they are also involved in hydrolysis through acetogenesis.

The DGGE band profiles and sequenced bands of ARC during the C1-C3 operations are shown in Figure 5(b) and Table 3, respectively. At the beginning of the reactor operation (C1), Uncultured Methanosaeta sp. (G3-H6-I6), Methanobacterium sp. (G1-H4-I4 and G2-H5-I5), and Methanomicrobiaceae (G4-H7-I7) in the startup seed were also detected in both the sludge and packed zones, with the exception of Uncultured Methanococcoides sp. (G5-I8), which was found only in the sludge zone. An increase of ARC diversity was observed as the first detected bands of I2 and H1-3. These were represented by Methanocaldococcus vulcanius M7 for acetoclastic methanogens and Uncultured Methanomicrobiales, Methanospirillum hungatei and Methanobacterium sp. for hydrogenotrophic methanogens. During the increase of organic pollutants from the $\mathrm{C} 1$ to the $\mathrm{C} 2$ and $\mathrm{C} 3$ operations, Uncultured Methanosaeta sp. (H6-I6-J6-K8L9-M6), Methanobacterium sp. (H4-I4-J4-K6-L7-M4 and H5-I5-J5-K7-L8-M5), Methanomicrobiaceae (H7-I7-J7-K9L10-M7) and Uncultured Methanomicrobiales (H1-I1-J1K1-L1-M1) were found in both the sludge and packed zones. The low intensity of the DGGE bands I8-J9-K11-L12M8 belonged to Uncultured Methanococcoides sp.; Methanosaeta sp. Is one of the acetoclastic methanogens presented in the startup seed and all operating conditions. Methanosaeta sp. is commonly found in stable anaerobic digestion systems and often represents the major ARC in methanogenic communities [36, 42]. More diversity of hydrogenotrophic methanogens was detected with an increase in the organic pollutant concentration (Table 3). Not only Methanobacterium sp. and Methanomicrobiaceae, but also other hydrogenotrophic methanogens such as Methanobacteriaceae (K5), Methanoculleus sp. (J8-K10-L11), Methanobacterium palustre (L5), and Methanobacterium sp. (L6) were also found among the sludge and the packed zones of the AHR. Two types of methanogenic ARC, acetoclastic and hydrogenotrophic methanogens were found under all the operating conditions for this study. Methanogenic acetate degradation was converted to methane by acetoclastic methanogens (Uncultured Methahnosaeta sp.), whereas hydrogen and $\mathrm{CO}_{2}$ were carried out by hydrogenotrophic methanogens (Methanobacterium sp, Methanomicrobiaceae, and Uncultured Methanomicrobiales). During the methanogenic mineralization process, oxidation of reduced compounds (alcohols and short-chain fatty acids) by acidogenic bacteria and/or acetogenic bacteria is thermodynamically unfavorable. The oxidation of these reduced compounds can proceed only if hydrogen partial pressure is kept low by coupling with hydrogen consuming methanogenesis [43]. Thus, interspecies hydrogen transfer between syntrophic fatty acid-oxidizing bacteria (Uncultured Bacteroidetes bacterium, Clostridiales bacterium, and Acetobacter sp.) and the hydrogenotrophic methanogens appeared for the oxidation of these substrates. Acetate is one of the most important intermediates for the methane production step in the anaerobic mineralization of organic substrates. Hattori [44] reported that methanogenic acetate degradation is carried out by either an acetoclastic reaction or an anaerobic acetate-oxidizing reaction (syntrophic acetate oxidation and hydrogenotrophic methanogenesis). Methanosaeta sp. has a high affinity for acetate, and the growth of this ARC is affected by the concentration of acetate. In addition, high concentrations of ammonia and volatile fatty acids are considered important factors for acetate metabolism. Acetoclastic methanogens are also known to be more sensitive to these compounds than hydrogenotrophic methanogens. Some studies $[45,46]$ found syntrophic acetate-oxidizing bacteria in the class of Clostridia within the phylum Firmicutes (acetate-oxidizing bacteria strain AOR and Clostridium ultunense) and hydrogenotrophic methanogens (Methanobacterium and Methanoculleus sp.) for methane production under these stresses. We seemed to observe a similar result in the operation of C3 for high concentration of SS and O\&G influent. There was the first detection of Uncultured Clostridiaceae bacterium within the phylum of Firmicutes in both the sludge zone (F4) and the packed zone (E4) (Figure 5(a) and Table 2) and hydrogenotrophic methnanogens (Methanobacterium paluster, L5, Methanobacterium sp., L6, and Methanoculleus sp., L11) in the packed zone (Figure 5(b) and Table 3).

3.3. Qualitative and Quantitative Microorganism. Quantitative changes in the 16S rRNA gene concentration were determined by real-time PCR, and microbial quality was studied by microbial activity determination in the sludge and packed zones under the three operating conditions. The microbial populations and activity of EUB and ARC are described in Table 4. Among the operating conditions of C1, $\mathrm{C} 2$, and $\mathrm{C} 3$, there was an evident variation in the EUB and ARC populations and activity in the sludge and packed zones of AHR. The level of concentration of organic pollutants had an effect on the microbial populations and activity as well as on the structure of the microbial communities in each zone. This result will impact the environmental condition (TVA/ Alk and $\mathrm{pH}$ ) and the process performance. Microbial populations in the startup seed, the 16S rRNA gene concentrations of the EUB and ARC were $1.2 \times 10^{7}$ and $8.2 \times$ $10^{4}$ copies $\mathrm{rDNA} / \mathrm{g}$ VSS, while their activity were $1.00 \mathrm{~g}$ $\mathrm{COD} / \mathrm{g}$ VSS a day and $0.12 \mathrm{~g} \mathrm{COD}-\mathrm{CH}_{4} / \mathrm{g}$ VSS a day, respectively. At the beginning of the reactor operation $(\mathrm{C} 1)$, the overall microbial populations increased, resulting mostly from organic carbon being utilized for microbial cell development. The paired $t$-test analysis of the EUB and ARC activity $(P \leq 0.05)$ indicated that under each of the conditions $\mathrm{C} 1, \mathrm{C} 2$, and $\mathrm{C} 3$ there was significantly different microbial activity in the reactor operation. The activity of the EUB and ARC in the sludge zone were close to those in the startup seed, while those in the packed zone were different. 
TABLE 4: Microbial populations and activities in startup seed, sludge, and packed zones of AHR under various operating conditions.

\begin{tabular}{|c|c|c|c|c|}
\hline \multirow[b]{2}{*}{ Condition/zone } & \multicolumn{2}{|c|}{ EUB } & \multicolumn{2}{|c|}{ ARC } \\
\hline & $\begin{array}{c}\text { Population } \\
\text { (Copies rDNA/g VSS) }\end{array}$ & $\begin{array}{c}\text { Activity } \\
\text { (g COD/g VSS day) }\end{array}$ & $\begin{array}{c}\text { Population } \\
\text { (Copies rDNA/g VSS) }\end{array}$ & $\begin{array}{c}\text { Activity } \\
\text { (g COD- } \mathrm{CH}_{4} / \mathrm{g} \text { VSS day) }\end{array}$ \\
\hline Startup seed & $1.2 \times 10^{7}$ & 1.00 & $8.2 \times 10^{4}$ & 0.12 \\
\hline \multicolumn{5}{|l|}{ Sludge zone } \\
\hline $\mathrm{C} 1$ & $3.5 \times 10^{8^{\mathrm{a}}}$ & $1.08^{\mathrm{a}}$ & $1.1 \times 10^{5^{\mathrm{a}}}$ & $0.10^{\mathrm{a}}$ \\
\hline $\mathrm{C} 2$ & $4.4 \times 10^{8^{b}}$ & $1.58^{\mathrm{b}}$ & $4.8 \times 10^{5^{b}}$ & $0.11^{\mathrm{b}}$ \\
\hline $\mathrm{C} 3$ & $6.4 \times 10^{9 \mathrm{c}}$ & $1.65^{\mathrm{c}}$ & $7.5 \times 10^{5^{c}}$ & $0.14^{\mathrm{c}}$ \\
\hline \multicolumn{5}{|l|}{ Packed zone } \\
\hline $\mathrm{C} 1$ & $9.0 \times 10^{7^{\mathrm{a}}}$ & $0.43^{\mathrm{a}}$ & $3.3 \times 10^{5^{\mathrm{a}}}$ & $0.18^{\mathrm{a}}$ \\
\hline $\mathrm{C} 2$ & $4.3 \times 10^{8^{\mathrm{b}}}$ & $0.74^{\mathrm{b}}$ & $8.4 \times 10^{5^{b}}$ & $0.25^{\mathrm{b}}$ \\
\hline $\mathrm{C} 3$ & $8.6 \times 10^{8^{c}}$ & $0.91^{\mathrm{c}}$ & $9.1 \times 10^{7^{c}}$ & $0.34^{c}$ \\
\hline
\end{tabular}

Values are the averages of three determinations taken at the end of operating conditions.

Averages followed by the different letter in the same column among operating condition C1-C3 are statically different at $95 \%$ level by the paired $t$-test.

EUB activity decreased and ARC activity slightly increased compared to that in the startup seed. When the organic pollutant concentration was increased to the $\mathrm{C} 2$ and $\mathrm{C} 3$ conditions, the population and activity of the EUB and ARC in the sludge and packed zones were investigated for the development of these characteristics and compared to those under the $\mathrm{C} 1$ conditions. In the sludge zone, the EUB population and activity were significantly increased from $3.5 \times 10^{8}$ to $6.4 \times 10^{9}$ copies $\mathrm{rDNA} / \mathrm{g}$ VSS, and 1.08 to $1.65 \mathrm{~g}$ $\mathrm{COD} / \mathrm{g}$ VSS, respectively, while the ARC population and activity were slightly increased from $1.1 \times 10^{5}$ to $7.5 \times 10^{5}$ copies $\mathrm{rDNA} / \mathrm{g}$ VSS and 0.10 to $0.14 \mathrm{~g}$ COD- $\mathrm{CH}_{4} / \mathrm{g}$ VSS a day. In addition, when comparing the packed and the sludge zones, the EUB population had decreased slightly, and the EUB activity was lower, whereas the ARC population and activity were higher, from $10^{5}$ to $10^{7}$ copies rDNA/g VSS and 0.1 to $0.3 \mathrm{~g} \mathrm{COD}-\mathrm{CH}_{4} / \mathrm{g}$ VSS a day. The sludge zone is the bottom part of the AHR, where there is the first contact with the influent POME. In this zone, most of the organic carbon was hydrolyzed to a simpler molecule and then converted to volatile fatty acids by hydrolytic, acidogenic and acetogenic bacteria. This resulted in the high TVA concentration and TVA/Alk ratio (Figure 4(a)). Contrary to the ARC characteristics, a higher population and activity were found in the microbial biofilm of the packed zone (Table 4). The packed zone was located in the top part of the AHR, where the remaining organic compounds were continuously converted to short chains of volatile fatty acids. This was reflected in the low activity of EUB, while the dominant ARC characteristics were evident in this packed zone. The ARC activity in the packed zone under operating conditions $\mathrm{C} 1$ to $\mathrm{C} 3$ was increased from 0.18 to $0.34 \mathrm{~g} \mathrm{COD}-\mathrm{CH}_{4} / \mathrm{g}$ VSS a day. This might relate to the uncomfortable environment for these ARC in the sludge zone due to the high TVA concentration, lower $\mathrm{pH}$, and high TVA/Alk; whereas, the dominant ARC biofilm can resist more than that in suspended cells and was able to utilize the TVA for its growth and methane production in the packed zone. This kept the process stable, with pH $6.9 \pm 0.4$ and TVA/Alk $0.35 \pm 0.05$. An increased ARC population and activity reflected the low TVA concentration $\left(<800 \pm 10 \mathrm{mg} \mathrm{CH}{ }_{3} \mathrm{COOH}\right)$ with a $\mathrm{pH}$ in the neutral range and a lower TVA/Alk ratio $(<0.5)$ in the packed zone. More methanogenesis occurred in this zone. The action of the sludge and packed zones, which work as hydrolysis or fermentative and methanogenesis zones, respectively, were mostly responsible for a properly enhanced reactor performance and maintained the process stability of the AHR. For POME, anaerobic digestion could be achieved completely within one reactor of an anaerobic hybrid reactor.

\section{Conclusions}

The process performance and stability, as well as the microbial characteristics, varied according to the organic pollutant concentrations. The organic pollutants were studied at OLR of 6.2-8.2 g COD/L day consisting of 5.2-10.2 g SS/L and $0.9-1.9 \mathrm{~g}$ O\&G/L. The AHR utilized in the study can handle the OLR to $8.2 \mathrm{~g} \mathrm{COD/L}$ day containing $10.2 \mathrm{~g} \mathrm{SS} / \mathrm{L}$ and $1.9 \mathrm{~g} \mathrm{O \& G/L}$ with high performance and stability. Process stability in terms of the TVA/Alk ratio and $\mathrm{pH}$ was in the range of $0.2-0.5$ and $6.5-7.0$, respectively. The increase of organic pollutant concentration affected the EUB and ARC communities, populations, and activity in the sludge and packed zones, which was reflected in the organic removal of TCOD, SS, and O\&G. Throughout the graduated $\mathrm{C} 1$ to $\mathrm{C} 3$ operating conditions, high organic hydrolysis/fermentation took place in the sludge zone of the AHR, and the dominant eubacteria were represented by Pseudomonas sp., Uncultured Bacteroidetes bacterium, and Clostridiales bacterium. Methane was produced from both of acetoclastic and hydrogenotrophic methanogens. The dominant archaeal bacteria found under all the operating conditions related to acetoclastic methanogens as Uncultured Methanosaeta sp. and hydrogenotrophic methanogens as Methanobacterium sp., Methanomicrobiaceae, and Uncultured Methanomicrobiales. Higher levels of archaeal population and activity were found in the packed zone within the microbial biofilm. From the results of the microbial characteristics, this implied that the sludge and packed zones in the AHR acted overall as acidification and methanation zones, respectively. 


\section{Acknowledgments}

The authors would like to express their sincere gratitude to the Joint Graduate School of Energy and Environment (JGSEE) for the Ph.D. scholarship and to the Excellent Center of Waste Utilization and Management (ECoWaste) for facility and experimental support. They would like to certify that there is no conflict of interests with Genbank regarding the materials and methods discussed in the paper.

\section{References}

[1] Palm Oil World, "Global Trade," 2012, http://www.palmoilworld.org/Globaltrade.htm.

[2] Department of Alternative Energy Development and Efficiency (DEDE), Ministry of Energy, Thailand Alternative Energy Situation, 2009.

[3] Department of Alternative Energy Development and Efficiency (DEDE), Ministry of Energy, Alternative Energy Development Plan: AEDP, 2012-2021, 2012.

[4] T. Y. Wu, A. W. Mohammad, J. M. Jahim, and N. Anuar, "Pollution control technologies for the treatment of palm oil mill effluent (POME) through end-of-pipe processes," Journal of Environmental Management, vol. 91, no. 7, pp. 1467-1490, 2010.

[5] P. E. Poh and M. F. Chong, "Development of anaerobic digestion methods for palm oil mill effluent (POME) treatment," Bioresource Technology, vol. 100, no. 1, pp. 1-9, 2009.

[6] A. L. Ahmad, S. Sumathi, and B. H. Hameed, "Coagulation of residue oil and suspended solid in palm oil mill effluent by chitosan, alum and PAC," Chemical Engineering Journal, vol. 118, no. 1-2, pp. 99-105, 2006.

[7] V. Limkhuansuwan and P. Chaiprasert, "Decolorization of molasses melanoidins and palm oil mill effluent phenolic compounds by fermentative lactic acid bacteria," Journal of Environmental Sciences, vol. 22, no. 8, pp. 1209-1217, 2010.

[8] Bureau of Water Technology and Industrial Pollution Management, Ministry of Industry, Environmental Management of Palm Oil Mill Industry, 1997.

[9] T. Y. Wu, A. W. Mohammad, J. M. Jahim, and N. Anuar, "A holistic approach to managing palm oil mill effluent (POME): biotechnological advances in the sustainable reuse of POME," Biotechnology Advances, vol. 27, no. 1, pp. 40-52, 2009.

[10] D. Karakashev, D. J. Batstone, and I. Angelidaki, "Influence of environmental conditions on methanogenic compositions in anaerobic biogas reactors," Applied and Environmental Microbiology, vol. 71, no. 1, pp. 331-338, 2005.

[11] B. Demirel and P. Scherer, "The roles of acetotrophic and hydrogenotrophic methanogens during anaerobic conversion of biomass to methane: a review," Reviews in Environmental Science and Biotechnology, vol. 7, no. 2, pp. 173-190, 2008.

[12] G. D. Najafpour, A. A. L. Zinatizadeh, A. R. Mohamed, M. Hasnain Isa, and H. Nasrollahzadeh, "High-rate anaerobic digestion of palm oil mill effluent in an upflow anaerobic sludge-fixed film bioreactor," Process Biochemistry, vol. 41, no. 2, pp. 370-379, 2006.

[13] R. Borja, C. J. Banks, Z. Wang, and A. Mancha, "Anaerobic digestion of slaughterhouse wastewater using a combination sludge blanket and filter arrangement in a single reactor," Bioresource Technology, vol. 65, no. 1-2, pp. 125-133, 1998.

[14] P. Chaiprasert, W. Suvajittanont, B. Suraraksa, M. Tanticharoen, and S. Bhumiratana, "Nylon fibers as supporting media in anaerobic hybrid reactors: it's effects on system's performance and microbial distribution," Water Research, vol. 37, no. 19, pp. 4605-4612, 2003.

[15] A. A. L. Zinatizadeh, B. Salamatinia, S. L. Zinatizadeh, A. R. Mohamed, and M. Hasnain Isa, "Palm oil mill effluent digestion in an up-flow anaerobic sludge fixed film bioreactor," International Journal of Environmental Research, vol. 1, no. 3, pp. 264-271, 2007.

[16] American Public Health Association, Standard Methods for the Examination of Water and Wastewater, American Public Health Association, American Public Association (APHA), Washington, DC, USA, 2005.

[17] AOAC, Official Method of Analysis, Association of Official Agricultural Chemists, Arlington, Va, USA, 21th edition, 2006.

[18] P. Panichnumsin, A. Nopharatana, B. Ahring, and P. Chaiprasert, "Production of methane by co-digestion of cassava pulp with various concentrations of pig manure," Biomass and Bioenergy, vol. 34, no. 8, pp. 1117-1124, 2010.

[19] J. Zhou, M. A. Bruns, and J. M. Tiedje, "DNA recovery from soils of diverse composition," Applied and Environmental Microbiology, vol. 62, no. 2, pp. 316-322, 1996.

[20] M. Khemkhao, B. Nuntakumjorn, S. Techkarnjanaruk, and C. Phalakornkule, "Effect of chitosan on UASB treating POME during a transition from mesophilic to thermophilic conditions," Bioresource Technology, vol. 102, no. 7, pp. 4674-4681, 2011.

[21] S. F. Altschul, W. Gish, W. Miller, E. W. Myers, and D. J. Lipman, "Basic local alignment search tool," Journal of Molecular Biology, vol. 215, no. 3, pp. 403-410, 1990.

[22] J. A. Whelan, N. B. Russell, and M. A. Whelan, "A method for the absolute quantification of cDNA using real-time PCR," Journal of Immunological Methods, vol. 278, no. 1-2, pp. 261269, 2003.

[23] A. Nopharatana, W. P. Clarke, P. C. Pullammanappallil, P. Silvey, and D. P. Chynoweth, "Evaluation of methanogenic activities during anaerobic digestion of municipal solid waste," Bioresource Technology, vol. 64, no. 3, pp. 169-174, 1998.

[24] R. Borja, A. Martín, B. Rincón, and F. Raposo, "Kinetics for substrate utilization and methane production during the mesophilic anaerobic digestion of two phases olive pomace (TPOP)," Journal of Agricultural and Food Chemistry, vol. 51, no. 11, pp. 3390-3395, 2003.

[25] E. O. Ugoji, "Anaerobic digestion of palm oil mill effluent and its utilization as fertilizer for environmental protection," Renewable Energy, vol. 10, no. 2-3, pp. 291-294, 1997.

[26] M. Beccari, F. Bonemazzi, M. Majone, and C. Riccardi, "Interaction between acidogenesis and methanogenesis in the anaerobic treatment of olive oil mill effluents," Water Research, vol. 30, no. 1, pp. 183-189, 1996.

[27] A. Rinzema, "Anaerobic digestion of long-chain fatty acids in UASB and expanded granular sludge bed reactors," Process Biochemistry, vol. 28, no. 8, pp. 527-537, 1996.

[28] J. Palatsi, M. Viñas, M. Guivernau, B. Fernandez, and X. Flotats, "Anaerobic digestion of slaughterhouse waste: main process limitations and microbial community interactions," Bioresource Technology, vol. 102, no. 3, pp. 2219-2227, 2011.

[29] G. Tchobanoglous, L. Fburton, and H. D. Stensel, Wastewater Engineering: Treatment and Reuse, McGraw Hill, New York, NY, USA, 4th edition, 2003.

[30] C. S. Lee, Biodegradation of oil and grease in upflow anaerobic sludge blanket reactor for palm oil mill effluent treatment [M.S. thesis], Faculty of Civil Engineering, University Teknologi Malaysia, 2006. 
[31] P. Grau, M. Dohanyos, and J. Chudoba, "Kinetics of multicomponent substrate removal by activated sludge," Water Research, vol. 9, no. 7, pp. 637-642, 1975.

[32] B. Suraruksa, A. Nopharatana, P. Chaiprasert, M. Tanticharoen, and S. Bhumiratana, "Microbial activity of biofilm during start-up period of anaerobic hybrid reactor at low and high upflow feeding velocity," Water Science and Technology, vol. 48, no. 8, pp. 79-87, 2003.

[33] T. P. Curtis and W. T. Sloan, "Prokaryotic diversity and its limits: microbial community structure in nature and implications for microbial ecology," Current Opinion in Microbiology, vol. 7, no. 3, pp. 221-226, 2004.

[34] T. Kobayashi, D. Yasuda, Y. Y. Li, K. Kubota, H. Harada, and H. Q. Yu, "Characterization of start-up performance and archaeal community shifts during anaerobic self-degradation of wasteactivated sludge," Bioresource Technology, vol. 100, no. 21, pp. 4981-4988, 2009.

[35] M. Ike, D. Inoue, T. Miyano et al., "Microbial population dynamics during startup of a full-scale anaerobic digester treating industrial food waste in Kyoto eco-energy project," Bioresource Technology, vol. 101, no. 11, pp. 3952-3957, 2010.

[36] D. Papaparaskevas, P. Christakopoulos, D. Kekos, and B. J. Macris, "Optimizing production of extracellular lipase from rhodotorula glutinis," Biotechnology Letters, vol. 14, no. 5, pp. 397-402, 1992.

[37] K. D. McMahon, P. G. Stroot, R. I. Mackie, and L. Raskin, "Anaerobic codigestion of municipal solid waste and biosolids under various mixing conditions-II: microbial population dynamics," Water Research, vol. 35, no. 7, pp. 1817-1827, 2001.

[38] H. G. Balows, M. Trüper, W. Dworkin, Harder, and K. H. Schleifer, The Prokaryotes: A Handbook on the Biology of Bacteria: Ecophysiology, Isolation, Identification, Applications, Springer, New York, NY, USA, 1998.

[39] L. Levén, A. R. B. Eriksson, and A. Schnürer, "Effect of process temperature on bacterial and archaeal communities in two methanogenic bioreactors treating organic household waste," FEMS Microbiology Ecology, vol. 59, no. 3, pp. 683-693, 2007.

[40] A. P. Trzcinski, M. J. Ray, and D. C. Stuckey, "Performance of a three-stage membrane bioprocess treating the organic fraction of municipal solid waste and evolution of its archaeal and bacterial ecology," Bioresource Technology, vol. 101, no. 6, pp. 1652-1661, 2010.

[41] B. Rinc'n, F. Raposo, R. Borja, J. M. Gonzalez, M. C. Portillo, and C. Saiz-Jimenez, "Performance and microbial communities of a continuous stirred tank anaerobic reactor treating two-phases olive mill solid wastes at low organic loading rates," Journal of Biotechnology, vol. 121, no. 4, pp. 534-543, 2006.

[42] M. A. Paixão, C. R. G. Tavares, R. Bergamasco, A. L. E. Bonifácio, and R. T. Costa, "Anaerobic digestion from residue of industrial cassava industrialization with acidogenic and methanogenic physical separation phases," Applied Biochemistry and Biotechnology A, vol. 84-86, pp. 809-819, 2000.

[43] A. J. M. Stams, F. A. M. de Bok, C. M. Plugge, M. H. A. van Eekert, J. Dolfing, and G. Schraa, "Exocellular electron transfer in anaerobic microbial communities," Environmental Microbiology, vol. 8, no. 3, pp. 371-382, 2006.

[44] S. Hattori, "Minireview: syntrophic acetate-oxidizing microbes in methanogenic environments," Microbes and Environments, vol. 23, no. 2, pp. 118-127, 2008.

[45] H. L. Drake, K. Kusel, and C. Matthies, "Acetogenic prokaryotes," in The Prokaryotes, M. Dworkin, S. Falkow, E. Rosenberg, K. H. Schleifer, and E. Stackebrandt, Eds., pp. 354-420, Springer, New Yrok, NY, USA, 3rd edition, 2007.
[46] A. Schnurer, F. P. Houwen, and B. H. Svensson, "Mesophilic syntrophic acetate oxidation during methane formation by a triculture at high ammonium concentration," Archives of Microbiology, vol. 162, no. 1-2, pp. 70-74, 1994. 

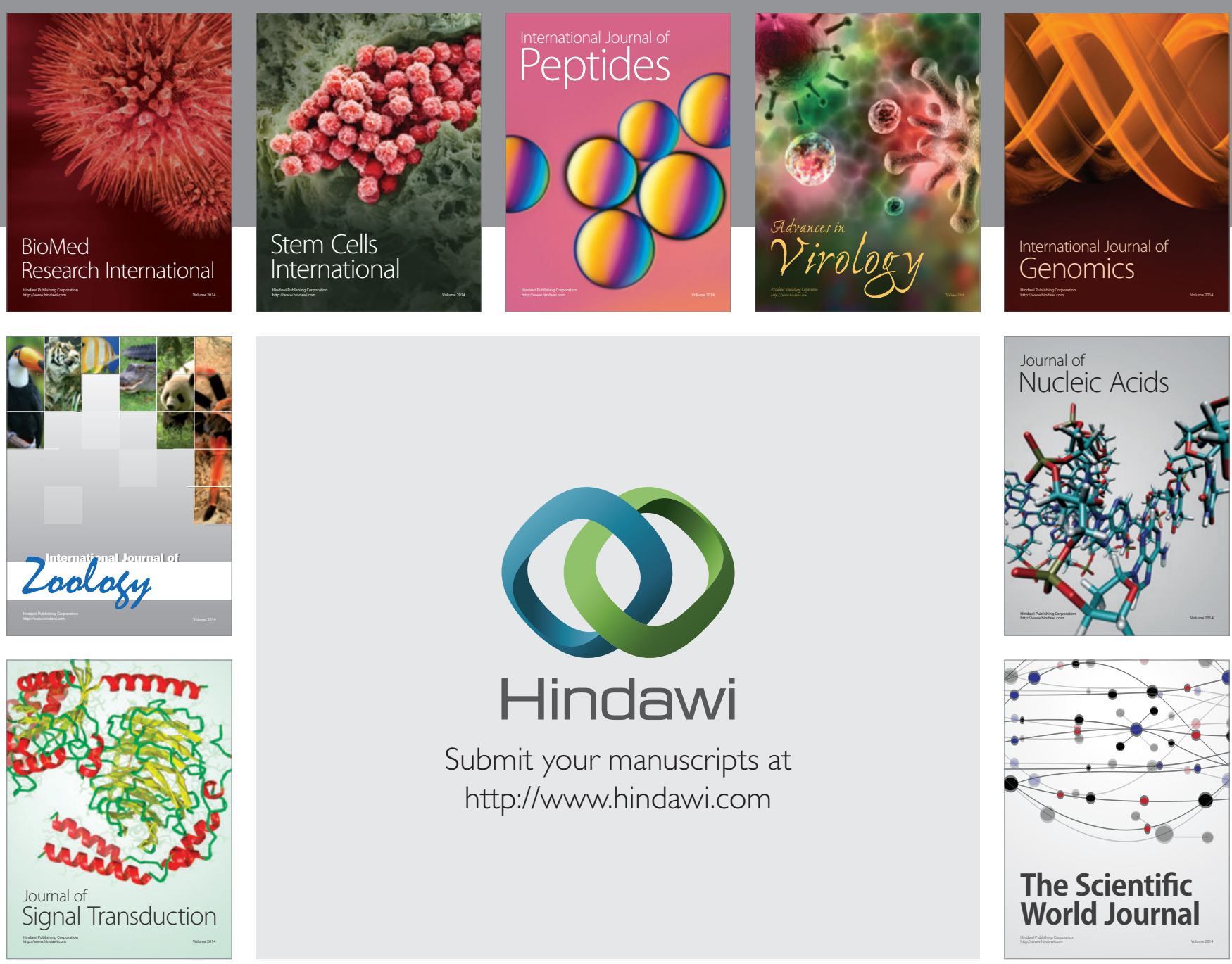

Submit your manuscripts at

http://www.hindawi.com
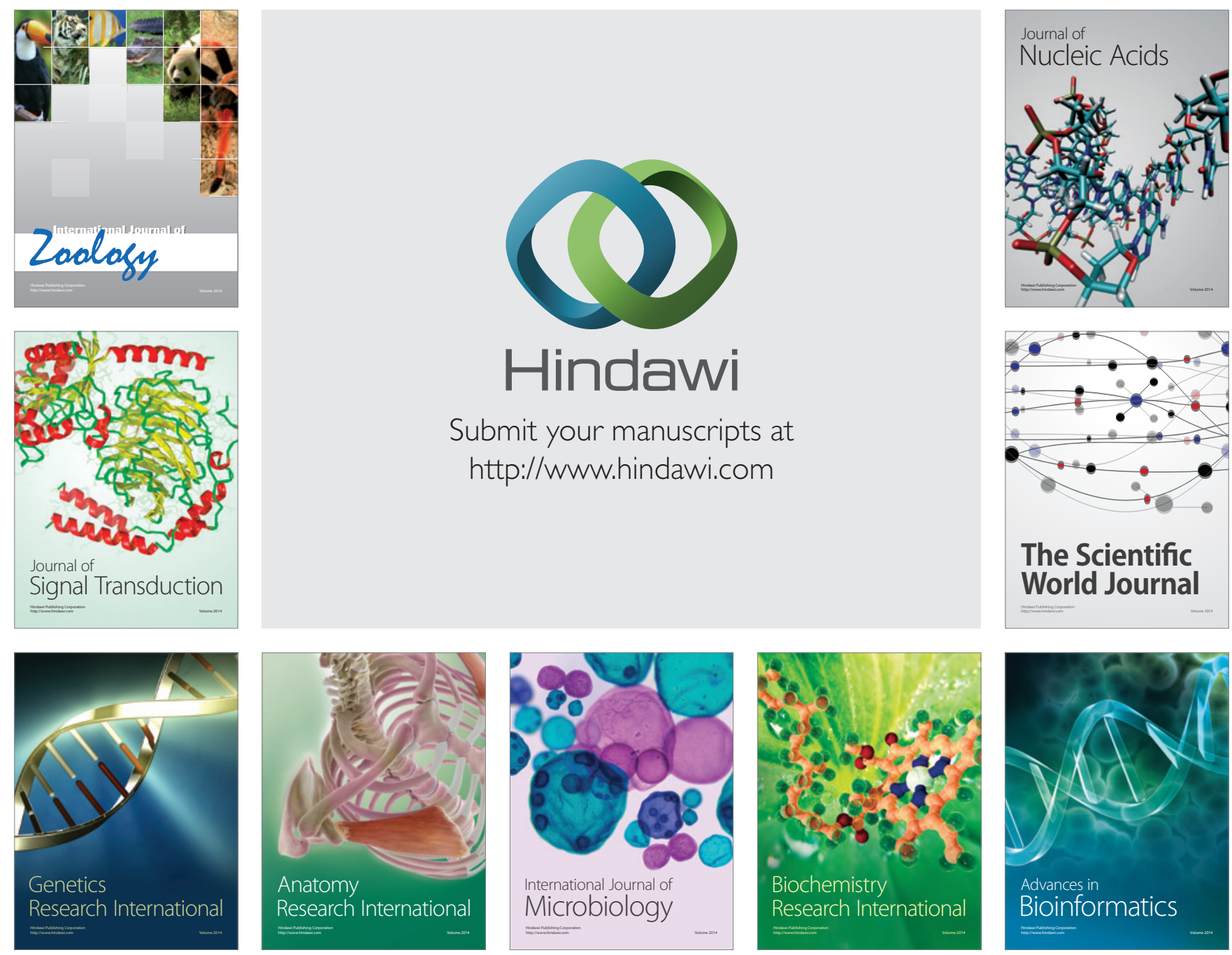

The Scientific World Journal
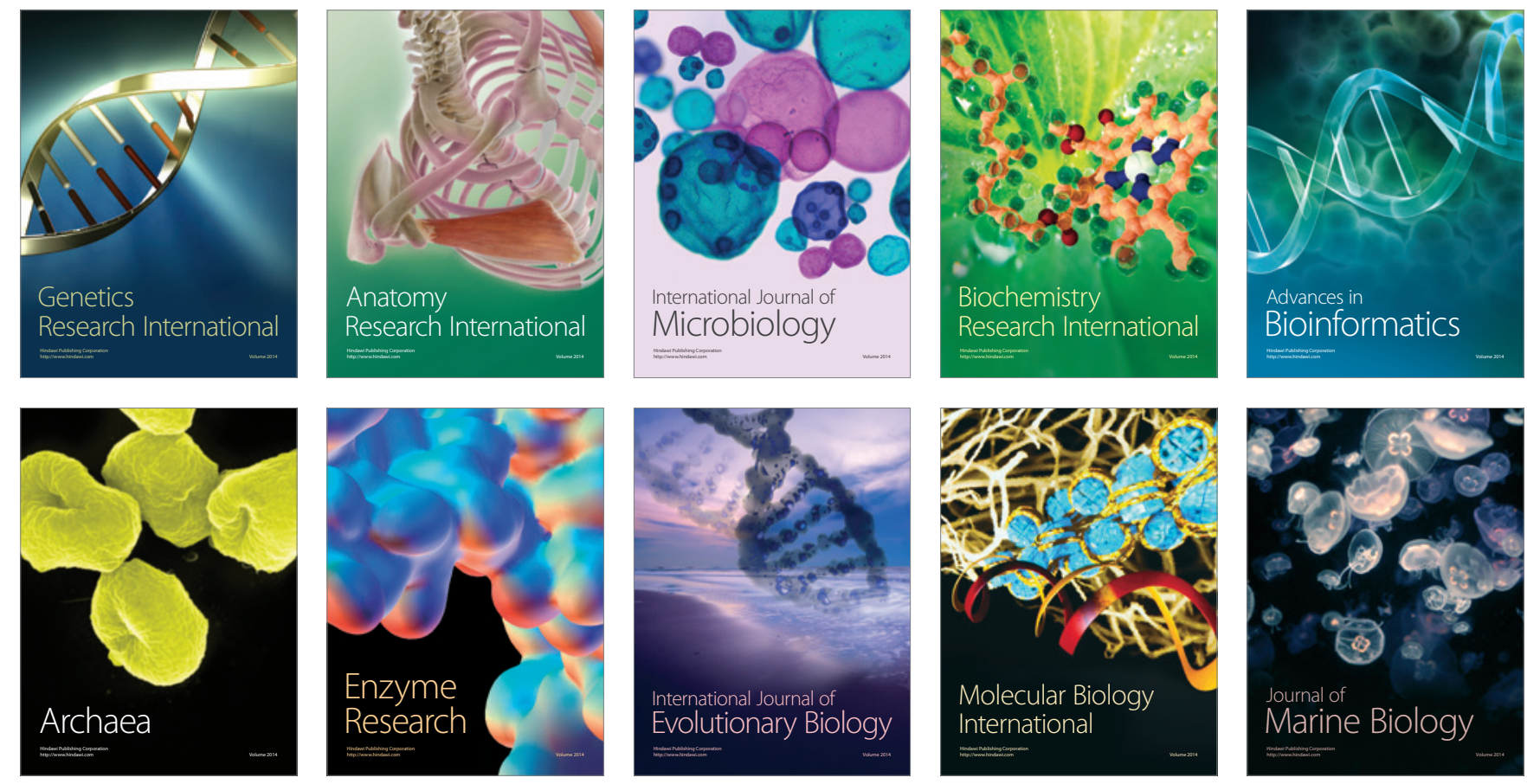